This article was downloaded by: [Universitaire De Lausanne]

On: 05 November 2013, At: 00:41

Publisher: Taylor \& Francis

Informa Ltd Registered in England and Wales Registered Number: 1072954 Registered office: Mortimer House, 37-41 Mortimer Street, London W1T 3J H, UK

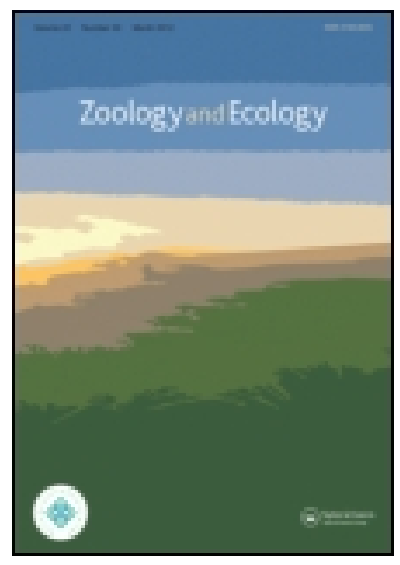

\title{
Zoology and Ecology
}

Publication details, including instructions for authors and subscription information: http:// www. tandfonline.com/loi/tzec20

\section{New record of Crocidura zarudnyi from Zabol, Iran}

Saeed Mohammadi ${ }^{a}$, Sylvain Dubey ${ }^{b} \&$ Ali Sabbaghzadeh ${ }^{a}$

${ }^{a}$ Faculty of Natural Resources, Department of Environmental Sciences, University of Zabol, Zabol , Iran

${ }^{b}$ Department of Ecology and Evolution, University of Lausanne, Lausanne, Switzerland Published online: 28 May 2013.

To cite this article: Saeed Mohammadi , Sylvain Dubey \& Ali Sabbaghzadeh (2013) New record of Crocidura zarudnyi from Zabol, Iran, Zoology and Ecology, 23:2, 162-164, DOI: 10.1080/21658005.2013.802105

To link to this article: http:// dx.doi.org/ 10.1080/21658005.2013.802105

\section{PLEASE SCROLL DOWN FOR ARTICLE}

Taylor \& Francis makes every effort to ensure the accuracy of all the information (the "Content") contained in the publications on our platform. However, Taylor \& Francis, our agents, and our licensors make no representations or warranties whatsoever as to the accuracy, completeness, or suitability for any purpose of the Content. Any opinions and views expressed in this publication are the opinions and views of the authors, and are not the views of or endorsed by Taylor \& Francis. The accuracy of the Content should not be relied upon and should be independently verified with primary sources of information. Taylor and Francis shall not be liable for any losses, actions, claims, proceedings, demands, costs, expenses, damages, and other liabilities whatsoever or howsoever caused arising directly or indirectly in connection with, in relation to or arising out of the use of the Content.

This article may be used for research, teaching, and private study purposes. Any substantial or systematic reproduction, redistribution, reselling, loan, sub-licensing, systematic supply, or distribution in any form to anyone is expressly forbidden. Terms \& Conditions of access and use can be found at http:// www.tandfonline.com/page/terms-and-conditions 


\title{
SHORT COMMUNICATION
}

\section{New record of Crocidura zarudnyi from Zabol, Iran}

\author{
Saeed Mohammadi $^{\mathrm{a}}$, Sylvain Dubey ${ }^{\mathrm{b}}$ and Ali Sabbaghzadeh ${ }^{\mathrm{a}}$ \\ ${ }^{a}$ Faculty of Natural Resources, Department of Environmental Sciences, University of Zabol, Zabol, Iran; ${ }^{b}$ Department of Ecology and \\ Evolution, University of Lausanne, Lausanne, Switzerland
}

(Received 13 March 2013; final version received 26 April 2013)

\begin{abstract}
The Zarudny's rock shrew, Crocidura zarudnyi Ognev, 1928, is found in very few localities in Afghanistan, Pakistan and Iran. Therefore, a record of the occurrence of additional populations of this species is very interesting. During surveys in Zabol (Iran), we caught three adult males of Crocidura sp. Based on external, dental and cranial measurements as well as genetic analyses, the individuals were identified as C. zarudnyi, which represents the first record of this species in this area.
\end{abstract}

\begin{abstract}
Kirstukas Crocidura zarudnyi Ognev, 1928 aptinkamas labai nedaugelyje Afganistano, Pakistano ir Irano vietovių, todèl naujos radimvietės yra svarbios rūšies paplitimo ịvertinimui. Tyrimų Zabole (Iranas) metu sugauti trys suaugę Crocidura $\mathrm{sp}$. patinèliai, kurie pagal išorinius, dantų ir kaukolès matmenis bei genetinès analizès rezultatus buvo identifikuoti kaip C. zarudnyi. Tai nauja rūšies radimvietė Zabole.
\end{abstract}

Keywords: Crocidura zarudnyi; Zabol; Iran

The Zarudny's rock shrew, Crocidura zarudnyi, was described by Ognev, 1928 based on a single specimen from the Baluchestan province in southeastern Iran and is currently known from very few localities in Afghanistan, Pakistan and Iran (Hassinger 1970; De Roguin 1988; Hutterer 2005; Dubey, Nová et al. 2007). It was only recently found that an additional specimen had been recorded in Pir sohrab, Chabahar in southeastern Iran (Baluchestan) and characterised morphologically, genetically and karyotypically by Dubey, Nová et al. (2007). The latter study revealed that $C$. zarudnyi is closely related to the widespread $C$. suaveolens group (see e.g. Dubey et al. 2006; Dubey, Cosson et al. 2007) and exhibits a similar karyotype $(2 N=40 ; \mathrm{FN}=50)$.

Twelve shrew species are currently known to occur in Iran (Ziaei 2008). The taxonomic status of many rare species such as the Zarudny's rock shrew is often uncertain and their range boundaries are also poorly known (Hutterer 2005; Esmaeili et al. 2008). So far, less than 20 specimens of the species have been collected (Dubey, Nová et al. 2007). Therefore, a record of the occurrence of additional populations of C. zarudnyi, although obtained accidentally, can be of interest.

During surveys in Zabol, Iran, we caught three adult males of C. zarudnyi on the 15 and 16 November 2012 at the campus of the University of Zabol $\left(31^{\circ} 02^{\prime} 28^{\prime \prime} \mathrm{N}\right.$, $61^{\circ} 32^{\prime} 04^{\prime \prime} \mathrm{E}$ ) (Figure 1). The caught specimens represent the first record of this species in this area. Our specimens were captured close to irrigation channels at the edge of fields and in cultivated lands overgrown with Medicago sativa, Haloxylon sp., Eucalyptus sp. and grape bushes.

The identification of specimens was carried out by external, dental and cranial measurements and genetic analyses. For genetic analyses, we extracted total cellular DNA using the DNeasy Tissue kit (Qiagen, Valencia, PA, USA) and amplified a fragment of the cytochrome-b gene by PCR using the primer pair L14724/H15149 (Irwin, Kocher and Wilson 1991). The amplification condition included 35 cycles of $60 \mathrm{~s}$ denaturation at $94^{\circ} \mathrm{C}$, $60 \mathrm{~s}$ annealing at $50^{\circ} \mathrm{C}$ and $120 \mathrm{~s}$ extension at $72^{\circ} \mathrm{C}$. The amplified products were sequenced with an $\mathrm{ABI}$ 3100 genetic analyzer (Applied Biosystems). To clarify the genetic relationship between the three samples of Crocidura from Iran and other Eurasian crocidurine shrews, we obtained additional DNA sequences from GenBank (Figure 2). Sorex minutus (Soricini) was used as an outgroup. Concerning maximum likelihood (ML) analyses, we selected the model of DNA substitution using the Bayesian Information Criterion (BIC; Schwarz 1978) implemented in JModeltest 0.1.1 (Guindon and Gascuel 2003; Posada 2008). The GTR + I + G model fit the data-set best. ML heuristic searches and bootstrap analyses (1000 replicates) were performed using

*Corresponding authors. Email addresses: smohammadi@uoz.ac.ir; sylvain.dubey@unil.ch

Saeed Mohammadi \& Sylvain Dubey contributed equally to this work. 


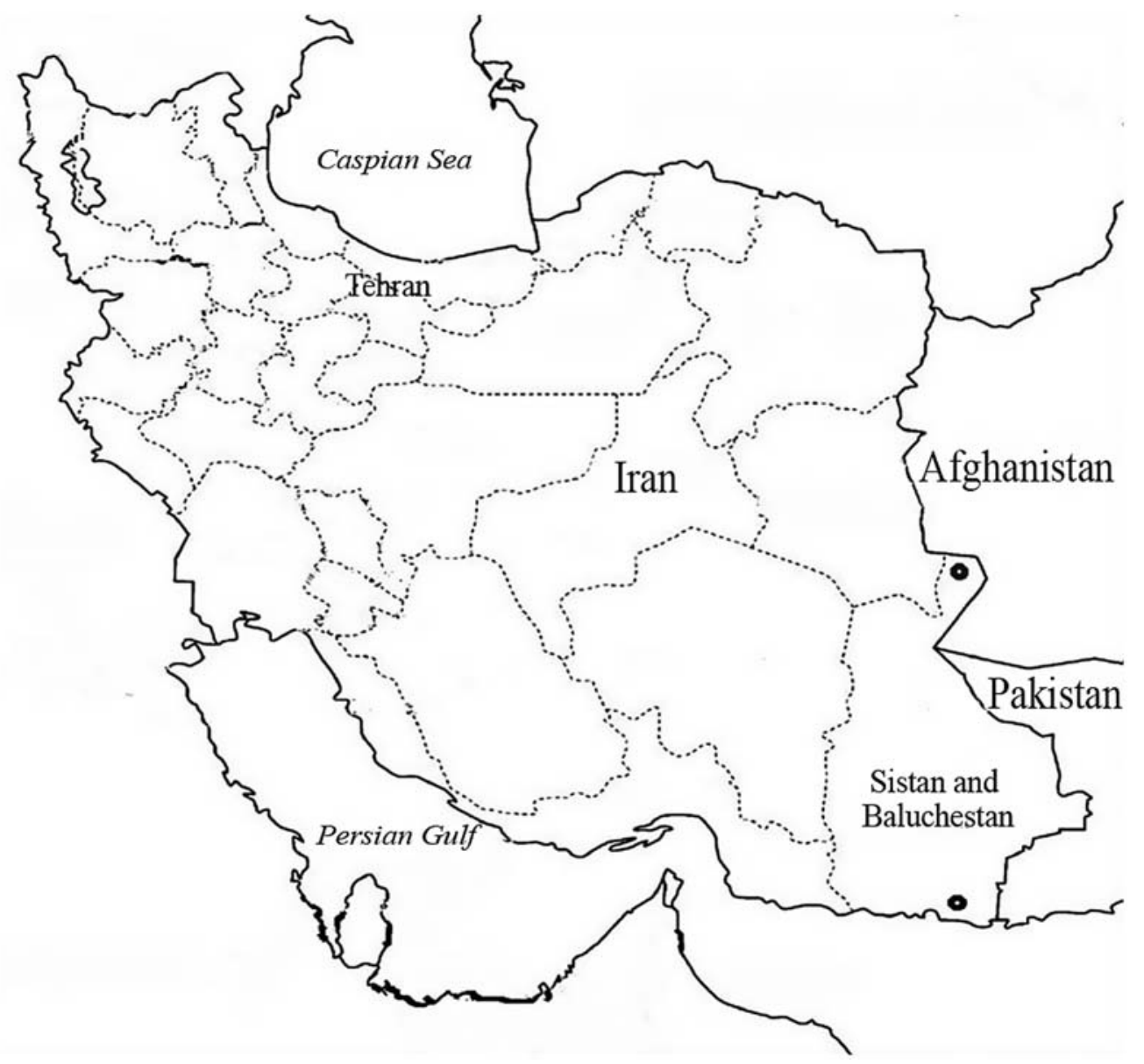

Figure 1. Map of Iran showing the geographical distribution of Zarudny's rock shrew; blue point: new record from Zabol, and black point: Pir sohrab in Chabahr (by Dubey, Nová et al. 2007).

Table 1. Measurements of Crocidura zarudnyi specimens (in $\mathrm{mm}$ ).

\begin{tabular}{|c|c|c|c|c|c|c|}
\hline \multirow[b]{2}{*}{ Characteristics } & \multicolumn{3}{|c|}{$\begin{array}{l}\text { This study } \\
\qquad(N=3)\end{array}$} & \multirow[b]{2}{*}{ Holotype Ognev (1928) } & \multirow[b]{2}{*}{ Specimen from Dubey, Nová et al. (2007) } & \multirow[b]{2}{*}{$\operatorname{Series}^{\mathrm{a}}(N=11-15)$} \\
\hline & 1 & 2 & 3 & & & \\
\hline Head and body length & 60 & 74 & 70 & - & - & - \\
\hline Tail length & 42 & 47 & 40 & 47.7 & 47 & - \\
\hline Hind foot length & 12 & 13 & 10 & - & - & - \\
\hline Weight, $g$ & 6 & 7 & 6 & - & - & - \\
\hline Condylobasal length & 13.1 & 18 & 14 & & 16.9 & $-(16.5-18.2)$ \\
\hline Zygomatic breadth & 5.5 & 8 & 5 & - & 5.5 & - \\
\hline Braincase height & 6.2 & 5 & 6 & - & - & - \\
\hline Height of mandible & 6 & 5 & 5.2 & - & - & - \\
\hline $\mathrm{P}_{4}-\mathrm{M}_{3}$ length & 5 & 4.5 & 5.5 & - & - & - \\
\hline
\end{tabular}

Note: ${ }^{a}$ Hassinger 1970 (specimens from Iran, West Pakistan, and Afghanistan).

PHYML with GTR $+\mathrm{I}+\mathrm{G}$ model (Guindon and Gascuel 2003).

The external and skull characteristics of the samples are presented in Table 1. The colouration of all specimens was almost identical. Dorsal pelage was dark greyish-brown and ventral pelage was distinctly paler and more greyish, but generally of a similar tinge as the dorsal pelage. The tail was unicoloured (Figure 3 ).
The cytochrome-b sequences (399 bp) of the three analysed individuals were identical (Genbank accession number: KC590097) and closely related to the previously published sequence of $C$. zarudnyi from Baluchestan (Genbank accession number: EF524711; Dubey, Nová et al. 2007), confirming our morphological identification (K2P distance: $0.3 \%$, corresponding to one transition in position 161 KC590097: $\mathrm{T}$ and EF524711: $\mathrm{C}\}$; see 


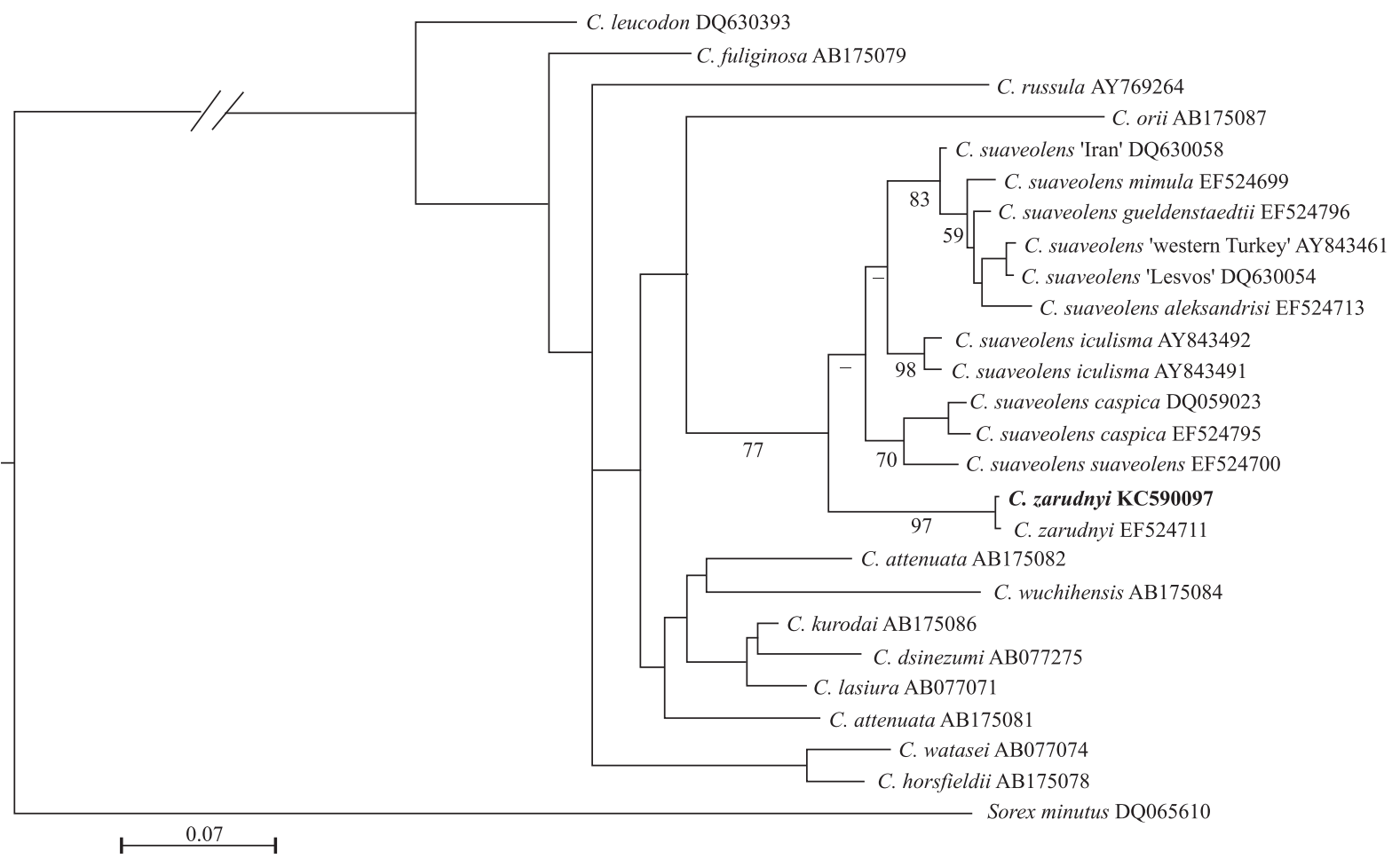

Figure 2. Phylogeny of the $399 \mathrm{bp}$ Cytb fragments analysed by ML analysis. Values in branches are bootstrap indices (1000 replications) of support for ML analyses for Crocidura zarudnyi and its close relative (in bold: sequence of C. zarudnyi from Zabol).

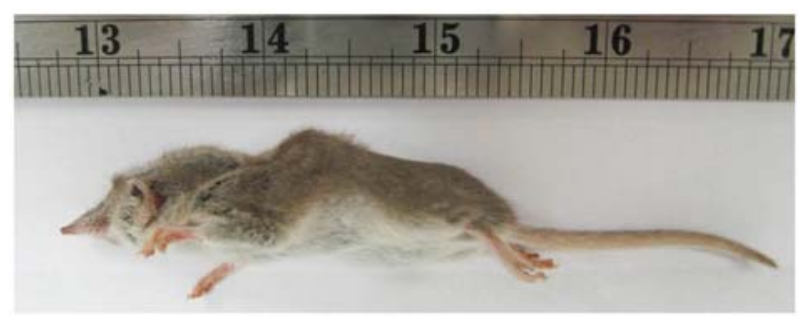

Figure 3. Zarudny's rock shrew (Crocidura zarudnyi) from Zabol, southeastern Iran.

Figure 2 for phylogenetic relationships with other Eurasian species).

\section{Acknowledgements}

We would like to thank B. Kryštufek and V. Vohralík for valuable comments, and the Swiss National Science Foundation (SNSF) for funding.

\section{References}

De Roguin, L. 1988. "Notes sur quelques mammiferes du Baluchistan Iranien [Notes on Some Mammals from the Iranian Baluchestan].” Revue Suisse De Zoologie 95: 595-606.

Dubey, S., M. Zaitsev, J.-F. Cosson, A. Abdukadier, and P. Vogel. 2006. "Pliocene and Pleistocene Diversification and Multiple Refugia in a Eurasian Shrew (Crocidura Suaveolens Group)." Molecular Phylogenetics and Evolution 38: 635-647.

Dubey, S., P. Nová, P. Vogel, and V. Vohralík. 2007. "Cytogenetic and Molecular Relationships between Zarudny's Rock Shrew (Crocidura Zarudnyi; Mammalia: Soricomorph) and Eurasian Taxa.” Journal of Mammalogy 88: 706-711.
Dubey, S., J.-F. Cosson, E. Magnanou, V. Vohralík, P. Benda, D. Frynta, R. Hutterer, V. Vogel, and P. Vogel. 2007. "Mediterranean Populations of the Lesser White-toothed Shrew (Crocidura Suaveolens Group): An Unexpected Puzzle of Pleistocene Survivors and Prehistoric Introductions." Molecular Ecology 16: 3438-3452.

Esmaeili, H. R., Gh. Gholamhosseini, H. Zareian, and B. Kryštufek. 2008. "Noteworthy Range Extension of Two White-toothed Shrews in Iran: Crocidura Suaveolens and Suncus Etruscus (Soricidae)." Zoology in the Middle East 45: $105-106$

Guindon, S., and O. Gascuel. 2003. "A Simple, Fast and Accurate Algorithm to Estimate Large Phylogenies by Maximum Likelihood." Systematic Biology 52: 692-704.

Hassinger, J. D. 1970. "Shrews of the Crocidura Zarudnyi Pergrisea Group with Descriptions of a New Subspecies." Fieldiana Zoology 58: 5-8.

Hutterer, R. 2005. "Order Soricomorpha." In Mammal Species of the World: A Taxonomic and Geographic Reference, edited by D. E. Wilson and D. M. Reeder, 3rd ed, 220-311. Baltimore, MD: Johns Hopkins University Press.

Irwin, D. M., T. D. Kocher, and A. C. Wilson. 1991. "Evolution of the Cytochrome B Gene of Mammals." Journal of Molecular Evolution 32: 128-144.

Ognev, S. I. 1928. Zveri vostochnoi Evropy i severnoi Azii. Tom I. Nasekomoyadnye i letuchie myshi [The mammals of the eastern Europe and the northern Asia. Vol. I. Insectivora and Chiroptera]. Moscow: Glavnauka.

Posada, D. 2008. "JModelTest: Phylogenetic Model Averaging." Molecular Biology and Evolution 25 (7): 1253-1256.

Schwarz, G. 1978. "Estimating the Dimension of a Model." Annals of Statistics 6: 461-464.

Ziaei, H. 2008. A Field Guide to the Mammals of Iran. Tehran: Iran Wildlife Center. 